\title{
Degree of Conversion and Mechanical Properties of Resin Cements Cured Through Different All-Ceramic Systems
}

\author{
Camila de Carvalho Almança Lopes ${ }^{1}$, Renata Borges Rodrigues ${ }^{1}$, André Luis \\ Faria e Silva ${ }^{3}$, Paulo Cézar Simamoto Júnior ${ }^{2}$, Carlos José Soares ${ }^{1}$, Veridiana \\ Resende Novais ${ }^{1}$
}

\begin{abstract}
The aim of this study was to verify the degree of conversion (DC), Vickers microhardness $(\mathrm{VH})$ and elastic modulus (E) of resin cements cured through different ceramic systems. One 1.5-mm-thick disc of each ceramic system (feldspathic, lithium dissilicate and zircônia veneered with feldspathic) was used. Three dual-cured (Allcem, Variolink II and RelyXU200) and one chemically-cured (Multilink) resin cements were activated through ceramic discs. For dual-cured resin cements was used a conventional halogen light-curing unit (Optilux 501 at $650 \mathrm{~mW} / \mathrm{cm} 2$ for $120 \mathrm{~s}$ ). Samples cured without the ceramic disc were used as control. The samples were stored at $37^{\circ} \mathrm{C}$ for $24 \mathrm{~h}$. ATR/FTIR spectrometry was used to evaluate the extent of polymerization in the samples $(n=5)$. Micromechanical properties $-\mathrm{VH}$ and $E$ - of the resin cements $(n=5)$ were measured with a dynamic indentation test. Data were statistically analyzed with two-way ANOVA, Tukey's test and Pearson's correlation $(\alpha=0.05)$. DC was affected only by the type of resin cement $(p=0.001)$. For $\mathrm{VH}$, significant interaction was detected between resin cement and ceramic $(p=0.045)$. The dual-cured resin cements showed no significant differences in mean values for $E$ and significantly higher values than the chemically-cured resin cement. The degree of conversion and the mechanical properties of the evaluated resin cements depend on their activation mode and the type of ceramics used in $1.5 \mathrm{~mm}$ thickness. The dual-cured resin cements performed better than the chemically-cured resin cement in all studied properties.
\end{abstract}

'Department of Operative Dentistry and Dental Materials, Dental School, UFU - Universidade Federal de Uberlândia. Uberlândia, MG, Brazil ${ }^{2}$ Department of Fixed Prosthodontics and Dental Materials, Dental School, UFU - Universidade Federal de Uberlândia. Uberlândia, MG, Brazil ${ }^{3}$ Department of Dentistry, Health and Biological Sciences Center, UFSE - Universidade Federal de Sergipe, Aracaju, SE, Brazil

Correspondence: Veridiana Resende Novais, Avenida Pará, 1720, Bloco 4L, Anexo A, Campus Umuarama, 38400-902 Uberlândia, MG, Brasil. Tel: +55-34-3218-2222. e-mail: veridianaresende@hotmail.com

\section{Introduction}

The interest in all-ceramic materials is on increase, since these materials have adequate physical and mechanical properties, excellent esthetic and biocompatibility that make them suitable for dental rehabilitation (1). However, the success of all-ceramic restorations depends largely on the reliable bonding between ceramic and dental hard tissues by luting materials.

With the developments in adhesive dentistry, resin cements became attractive because of their low solubility, good esthetics, and proper bond strength to both tooth substrate and restorative materials (2). These materials can be classified according to their activation modes, since the activation can be chemical, physical (by light) or combination of both (dual) (3). When the restoration thickness is above $1.5-2 \mathrm{~mm}$ or its opacity hinders the light transmission, the use of dual- or chemicallycured resin cements has been advocated $(4,5)$ to attain proper polymerization of resin cements. Inadequate polymerization, characterized by low degree of conversion (DC), decreases the mechanical properties of cement and increases water sorption and solubility. Furthermore, it was shown that increased amount of residual monomers may cause pulp irritation and irreversible pulpitis (6).
Insufficient DC can negatively affect the mechanical properties, alter dimensional stability, and decrease the bonding of resin cements to tooth structures, impairing the clinical longevity of restorations $(1,7,8)$.

The type of ceramics, their thickness, shade and translucency, the resin cement composition, mode of activation as well as the curing light output power, setting time and distance are factors that affect the resin cement polymerization $(1,5,9,10)$. The glass ceramic systems, feldspathic, leucite and lithium disilicate systems have pleasing aesthetics, are amenable to acid etching and present translucency that allows light transmission through the restoration to underlying tooth structure. However, higher strength ceramic systems, such as alumina or zirconia-based ceramics are required as substructure, as these ceramics used as coping have high opacity and can hinder the light transmission (11).

It is therefore important to assess the way in which the type of ceramic system may interfere in properties of different resin cements, in order to better understand the interaction between ceramic and luting material. Thus, the aim of this study was to evaluate DC, Vickers microhardness (VH) and elastic modulus (E) of resin cements cured under different ceramic systems. 
The tested null hypothesis was that ceramic type and the type of resin cement would have no significant influence on the mechanical properties of the resin cements.

\section{Material and Methods}

\section{Preparation of Ceramic Discs}

Three all-ceramic materials were selected for this study: feldspathic glass-ceramic (Noritake EX 3; Kuraray, Miyoshi, Chugoku, Japan); low translucency lithium disilicate glassceramic (IPS e-max Press LT; Ivoclar Vivadent, Schaan, Liechtenstein) and polycrystalline zirconia ceramic (Lava All-Ceramic System; 3M ESPE, Seefeld, Bavaria, Germany). For the last one, a feldspathic ceramic (Noritake EX 3) was applied over the core made from zirconia ceramic. For the feldspathic glass-ceramic, a machined metal pattern was duplicated with silicon (Aerojet; São Paulo, SP, Brazil) and used to manufacture the feldspathic ceramic disc. The feldspathic ceramic was sintered (Alumini Press II; EDG, São Carlos, SP, Brazil) according to the manufacturer's instructions. IPS e-max Press ceramic discs were prepared by the heat-pressing technique in specific furnace (Ivoclar Vivadent) following the manufacturer's instructions. An opaque zircon disc was milled in the Zirkonzahn CAD/ CAM (Zirkonzahn Worldwide, Gais, Italy) system using zircon blanks (0.3 $\mathrm{mm}$ thick) and a feldspathic ceramic was applied onto the fabricated 1.2-mm-thick zirconia disc. Three ceramic discs were $1.5 \mathrm{~mm}$ thick, $10 \mathrm{~mm}$ in diameter and Vita shade A2 color. Next, the samples were stored at room temperature. The light transmission through ceramics was measured with radiometer (Demetron; Kerr, Orange, CA, USA).

\section{Preparation of Resin Cement Samples through Ceramic Discs}

Three dual-cured (Allcem, Variolink II and RelyX U200) and one chemically-cured (Multilink) resin cements were selected for this study. All resin cements information is summarized in Table 1. The resin cements were manipulated as recommended by manufacturers and inserted into vinyl molds $(1 \mathrm{~mm}$ thick $\times 2 \mathrm{~mm}$ inner diameter $\times 10 \mathrm{~mm}$ outer diameter). Mylar strips (Quimidrol; Joinville, SC, Brazil) were used on the bottom and top surfaces of the sample to ensure smooth surfaces, allow the ceramic disc placement over the sample and avoid inhibition of polymerization by oxygen (12). The cements were mixed in controlled temperature $23( \pm 1){ }^{\circ} \mathrm{C}$ and $40 \%$ relative humidity. The ceramic discs were placed over the resin cement samples assisted with a teflon positioning ring and waited five minutes for chemical setting of the cements (13). The samples were shielded from room light by positioning a dark compartment over the samples, during the five minutes of chemical setting. The light curing was performed for the dual-cured resin cements through the ceramic discs for $40 \mathrm{~s}$ on the top and on both sides of the samples to simulate light-activation on the occlusal, lingual and buccal surfaces. Each sample was submitted to light exposure for $120 \mathrm{~s}$ (12), using a halogen light-curing unit (Optilux 501; Kerr) at $650 \mathrm{~mW} /$ $\mathrm{cm}^{2}$. Samples from each cement group cured without the ceramic disc were used as control samples. All samples were stored under dry and dark conditions at $37{ }^{\circ} \mathrm{C}$ for $24 \mathrm{~h}$.

\section{Degree of Conversion}

The DC of the samples $(n=5)$ was determined using

Table 1. Resin cements assessed in this study

\begin{tabular}{|c|c|c|c|c|}
\hline Material & Manufacturer & $\begin{array}{l}\text { Classification/ } \\
\text { activation mode }\end{array}$ & Composition* & $\begin{array}{l}\text { Filler content } \\
\text { (vol. } \%)\end{array}$ \\
\hline Allcem & $\begin{array}{l}\text { FGM, Joinvile, } \\
\text { SC, Brazil }\end{array}$ & $\begin{array}{c}\text { Regular/ } \\
\text { Dual-cured }\end{array}$ & $\begin{array}{l}\text { Bis-GMA, Bis-EMA, TEGDMA, co-initiators, initiators (camphorquinone } \\
\text { and Dibenzoyl peroxide), inorganic fillers (Barium alumo- } \\
\text { silicate glass and silicon dioxide), pigments and stabilizers. }\end{array}$ & $66-67$ \\
\hline $\begin{array}{l}\text { RelyX } \\
\text { U200 }\end{array}$ & $\begin{array}{l}\text { 3M ESPE, } \\
\text { Seefeld, } \\
\text { Germany }\end{array}$ & $\begin{array}{l}\text { Self-adhesive/ } \\
\text { Dual-cured }\end{array}$ & $\begin{array}{l}\text { Base Paste - Methacrylate monomers containing phosphoric } \\
\text { acid groups, methacrylate monomers, silanated fillers, } \\
\text { initiator components, stabilizers, rheological additives; } \\
\text { Catalyst Paste - Methacrylate monomers, alkaline (basic) fillers, silanated } \\
\text { fillers, initiator components, stabilizers, pigments, rheological additives. }\end{array}$ & 72 \\
\hline Variolink 11 & $\begin{array}{l}\text { lvoclar Vivadent, } \\
\text { Schaan, } \\
\text { Liechtenstein }\end{array}$ & $\begin{array}{c}\text { Regular/ } \\
\text { Dual-cured }\end{array}$ & $\begin{array}{l}\text { Bis-GMA, TEGDMA, UDMA, inorganic fillers (barium glass, } \\
\text { ytterbium trifluoride, Ba-Al-fluorosilicate glass, and spheroid } \\
\text { mixed oxide), initiators, stabilizers, pigments, benzoyl peroxide. }\end{array}$ & $\begin{array}{c}\text { Base }-46.7 \\
\text { Catalyst }-43.6\end{array}$ \\
\hline Multilink & $\begin{array}{l}\text { lvoclar Vivadent, } \\
\text { Schaan, } \\
\text { Liechtenstein }\end{array}$ & $\begin{array}{l}\text { Regular/ } \\
\text { Chemically- } \\
\quad \text { cured }\end{array}$ & $\begin{array}{l}\text { Bis-EMA, UDMA, Bis-GMA, HEMA, inorganic fillers } \\
\text { (barium glass, ytterbium trifluoride, spheroid mixed } \\
\text { oxid), initiators, stabilizers and pigments. }\end{array}$ & 39.7 \\
\hline
\end{tabular}

* According to manufacturers. Bis-GMA: 2,2-bis[p-(2'-hydroxy-3'methacryloxypropoxy)phenyl]propane; TEGDMA: triethylene glycol dimethacrylate; Bis-EMA: ethoxylated bisphenol A dimethacrylate; UEDMA: 1,6-bis(methacryloxy-2-ethoxycarbonylamino)-2,4,4-trimethylhexane; HEMA: hydroxyethylmethacrylate. 
attenuated total reflectance/Fourier transform infrared spectroscopy (ATR/ FTIR Vertex 70; Bruker, Ettlingen, Germany). Preliminary reading for a small amount of each uncured material was recorded in absorbance spectrum acquired by scanning the samples 32 times over a 4,000 to $400 \mathrm{~cm}^{-1}$ range with a resolution of $4 \mathrm{~cm}^{-1}$. Additional spectrum was obtained from cured specimen after dry storage at $37{ }^{\circ} \mathrm{C}$ for $24 \mathrm{~h}$ and shielded from the room light. Shielding was performed by keeping the material inside the closed sample compartment. The ratio between aliphatic carbon-to-carbon double bond (at 1,637 $\left.\mathrm{cm}^{-1}\right)$ and aromatic component group (at 1,608 $\mathrm{cm}^{-1}$ ) for uncured and cured samples were used to calculate the DC according to the following equation:

$$
\begin{aligned}
& \% \mathrm{DC}=1-\left[\operatorname{abs}\left(\mathrm{C}=\mathrm{C}_{\text {aliphatic }}\right) / \operatorname{abs}\left(\mathrm{C}=\mathrm{C}_{\text {aromatic }}\right)\right] \text { polymer } / \\
& {\left[\operatorname{abs}\left(\mathrm{C}=\mathrm{C}_{\text {aliphatic }}\right) / \operatorname{abs}\left(\mathrm{C}=\mathrm{C}_{\text {aromatic }}\right)\right] \text { monomer } \times 100}
\end{aligned}
$$

where $D C$ is the degree of conversion, $A b s\left(C=C_{\text {arom }}\right)$ is the height of the benzene ring peak, and $A b s\left(C=C_{\text {aliph }}\right)$ is the height of the aliphatic $\mathrm{C}=\mathrm{C}$ bond peak, for both cured and uncured resin cements $(14,15)$.

\section{Vickers Microhardness and Elastic Modulus}

The samples were embedded in polyester resin (Instrumental; São Paulo, SP, Brazil). Prior to testing, the surfaces were finished with 600,800, 1200 and 2000grit silicon-carbide papers sizes (Norton; Campinas, SP, Brazil) and polished with metallographic diamond pastes with 6-, 3-, 1-, and 1/4 $\mu \mathrm{m}$ - sizes (Arotec; São Paulo, SP, Brazil) (16). Cement samples were ultrasonically cleaned (Cristofoli; Campo Mourão, PR, Brazil) for $10 \mathrm{~min}$. VH measurements were performed on the top surface of resin cement using micro-hardness dynamic indenter (Micro Indentation Tester; CSM, Peseux, Switzerland). The test load was increased and decreased at a constant speed between 0 and $500 \mathrm{mN}$. The force increased from 0 to $500 \mathrm{mN}$ in $20 \mathrm{~s}$ intervals, applied constantly for $5 \mathrm{~s}$. Then the force was gradually removed from $500 \mathrm{mN}$ to $0 \mathrm{mN}$ in 20 s intervals. The load and the penetration depth of the indenter were continuously measured while loading-unloading the force. Five measurements were performed for each resin cement sample and the mean value was established as the Vickers hardness number (VHN) for statistical analysis $(n=5)$.

From a multiplicity of measurements stored in a database supplied by the manufacturer, a conversion factor between hardness and VHN was calculated and introduced into the software, so that the measurements were expressed in Vickers hardness units:

$\mathrm{VHN}=\underline{\mathrm{P}}$

where: $P$ is the maximum load; $A$ is the depth-sensing instrument.

The indentation modulus was calculated from the slope of the indentation tangent depth-curve at maximum force and is comparable with the elasticity modulus of the material.

\section{Statistical Analysis}

$\mathrm{DC}, \mathrm{VH}$ and $\mathrm{E}$ data were individually analyzed using two-way ANOVA, with ceramics and resin cement as the factors. All post hoc multiple comparisons were performed using Tukey's test. Pearson's correlation coefficient test was used to analyze a possible correlation between the analyzed three mechanical properties. Statistical significance was set at $\alpha=0.05$.

\section{Results}

Light transmission values of the ceramic discs are shown in Table 2.

\section{Degree of Conversion}

The mean DC values and standard deviations according to the ceramic type and resin cement type are shown in Table 3 . The factor resin cement type $(p=0.001)$ was significant for $D C$. The factors ceramic type $(p=0.703)$ and interaction between the study $(p=0.056)$ were not significant. Tukey

Table 2. Energy density values $\left(\mathrm{mW} / \mathrm{cm}^{2}\right)$ measured through different types of ceramic discs

\begin{tabular}{lcc}
\hline Ceramic type & Energy density & $\begin{array}{c}\text { \% of delivered } \\
\text { energy }\end{array}$ \\
\hline Feldspathic & 142 & 21.8 \\
Lithium disilicate & 135 & 20.8 \\
Zirconia + feldspathic & 75 & 11.5 \\
\hline
\end{tabular}

Table 3. Mean values and standard deviations of DC (\%) for the experimental groups

\begin{tabular}{lccccc}
\hline \multirow{2}{*}{$\begin{array}{l}\text { Resin } \\
\text { cement }\end{array}$} & \multicolumn{4}{c}{ Ceramic } & \multirow{2}{*}{$\begin{array}{c}\text { Pooled } \\
\text { Average }\end{array}$} \\
\cline { 2 - 5 } & Feldspathic & $\begin{array}{c}\text { Lithium } \\
\text { disilicate }\end{array}$ & $\begin{array}{c}\text { Zirconia }+ \\
\text { Feldspathic }\end{array}$ & Control & \\
\hline Allcem & $87.7(0.8)$ & $87.9(1.2)$ & $87.5(1.5)$ & $85.7(2.2)$ & $87.2(1.4)$ A \\
Variolink 11 & $68.1(1.8)$ & $60.5(7.5)$ & $63.0(5.9)$ & $66.6(4.7)$ & $64.5(4.9)$ C \\
RelyX U200 & $70.3(2.8)$ & $70.8(5.6)$ & $70.6(2.9)$ & $66.3(3.6)$ & $69.5(3.7)$ B \\
Multilink & $57.8(4.1)$ & $60.9(2.2)$ & $56.7(7.9)$ & $61.3(3.6)$ & $59.1(4.4)$ D \\
\hline
\end{tabular}

* For pooled average, different letters represent statistically significant differences (2-way ANOVA/Tukey, $\mathrm{p}<0.05)$. 
HDS showed differences among resin cements; chemicallycured resin cement exhibited the lowest values for DC.

\section{Vickers Microhardness}

There was statistical significance for resin cement $(p<0.001)$, ceramic $(p<0.001)$ and interaction between these factors $(p=0.045)$. The means and standard deviations for $\mathrm{VH}$ are in Table 4. The chemically-cured cement showed lower $\mathrm{VH}$ values than the dual-cured cements. When cured without the interposition of a ceramic disc or through feldspathic ceramic, Allcem and RelyXU200 presented the highest $\mathrm{VH}$ values Nevertheless, when cured through lithium disilicate and zirconia + feldspathic ceramic, RelyXU200 showed the highest values and Allcem resembled the other two dual-cured resin cements. The control group had the highest VH values for all studied cements or resembled the ceramics.

\section{Elastic Modulus}

The means and standard deviations for $E$ are in Table 5. The factor resin cement was significant $(p<0.001)$; no significant difference was found for the factor ceramic type $(p=0.287)$ and interaction between the ceramic and resin cement $(p=0.259)$. Dual-cured resin cements showed

Table 4. Mean values and standard deviations of $\mathrm{VH}\left(\mathrm{N} / \mathrm{mm}^{2}\right)$

\begin{tabular}{lcccc}
\hline \multirow{2}{*}{$\begin{array}{l}\text { Resin } \\
\text { Cement }\end{array}$} & \multicolumn{4}{c}{ Ceramic } \\
\cline { 2 - 5 } & Feldspathic & $\begin{array}{c}\text { Lithium } \\
\text { disilicate }\end{array}$ & $\begin{array}{c}\text { Zirconia }+ \\
\text { Feldspathic }\end{array}$ & Control \\
\hline Allcem & $70.6(8.2) \mathrm{Aab}$ & $67.4(13.6) \mathrm{ABb}$ & $71.1(4.2) \mathrm{ABab}$ & $74.4(4.7) \mathrm{Aa}$ \\
Variolink 11 & $59.0(5.4) \mathrm{Bb}$ & $55.9(4.4) \mathrm{Bb}$ & $67.9(4.0) \mathrm{Ba}$ & $60.7(7.6) \mathrm{Bab}$ \\
RelyX U200 & $67.6(8.1) \mathrm{Ab}$ & $70.7(8.0) \mathrm{Aab}$ & $76.2(10.5) \mathrm{Aa}$ & $70.0(10.4) \mathrm{Aab}$ \\
Multilink & $44.4(5.0) \mathrm{Ca}$ & $42.6(3.2) \mathrm{Ca}$ & $43.7(4.8) \mathrm{Ca}$ & $44.0(6.3) \mathrm{Ca}$ \\
\hline
\end{tabular}

The means followed by different letters (upper case letters within the columns and lower case letters within the rows) are significantly different (statistical categories defined by Tukey test; $p<0.05)$.

Table 5. Means and standard deviations of E (GPa) obtained according to the experimental groups

\begin{tabular}{|c|c|c|c|c|c|}
\hline \multirow{2}{*}{$\begin{array}{l}\text { Resin } \\
\text { Cement }\end{array}$} & \multicolumn{4}{|c|}{ Ceramic } & \multirow{2}{*}{$\begin{array}{c}\text { Pooled } \\
\text { average }\end{array}$} \\
\hline & Feldspathic & $\begin{array}{l}\text { Lithium } \\
\text { disilicate }\end{array}$ & $\begin{array}{c}\text { Zirconia + } \\
\text { Feldspathic }\end{array}$ & Control & \\
\hline Allcem & $10.3(0.6)$ & $8.9(2.1)$ & $10.0(0.6)$ & $10.5(0.5)$ & $9.9(0.9) \mathrm{A}$ \\
\hline Variolink 11 & $9.6(1.1)$ & $9.9(0.7)$ & $9.8(0.6)$ & $9.5(0.5)$ & $9.7(0.7) \mathrm{A}$ \\
\hline RelyX U200 & $10.3(0.7)$ & $10.0(0.9)$ & $10.0(0.6)$ & $10.1(1.0)$ & $10.1(0.8) \mathrm{A}$ \\
\hline Multilink & $8.5(0.6)$ & $7.9(0.6)$ & $8.2(0.6)$ & $8.0(1.1)$ & $8.2(0.7) \mathrm{B}$ \\
\hline
\end{tabular}

For pooled average, different letters represent statistically significant differences (2-way ANOVA/Tukey, $\mathrm{p}<0.05$ ). similar values for $\mathrm{E}$ and significantly higher values than the chemically-cured resin cement.

\section{Pearson's Correlation}

The Pearson's correlation test revealed a moderate correlation between DC and $\mathrm{VH}\left(\mathrm{r}^{2}=0.594\right)$ and between the $D C$ and $E\left(r^{2}=0.389\right)$ and a strong correlation between $\mathrm{VH}$ and $\mathrm{E}\left(\mathrm{r}^{2}=0.804\right)$.

\section{Discussion}

Traditionally, DC is used to investigate factors affecting the polymerization reaction; whereas the final DC of a polymer has important effect on the mechanical properties (17). It is important to emphasize that beyond polymerization efficiency measured by $\mathrm{DC}$, other factors affect the mechanical properties of resin cements and, consequently, the clinical performance of adhesively luted restorations (18). In the current study, mechanical properties were assessed using a dynamic indentation test that provides both hardness and modulus of elasticity of the material directly from indentation load and displacement measurements (19). A strong correlation between these mechanical properties was shown, but weaker correlations were found between both mechanical properties and DC.

The polymerization depends on several factors, including resin cement composition and activation mode. Regarding activationmode, the lowest values of $\mathrm{DC}, \mathrm{VH}$ and $\mathrm{E}$ were observed for the chemically-activated cement. The amount of initiators (usually benzoyl peroxide and an amine) added to resin cements to produce chemical activation of the polymerization reaction is limited to allow longer working time. Considering that the final DC of the chemically-activated cement is proportional to the amount of chemical initiators, were expected reduced values of DC (20). Chemical-activation also is present in dual cured cement, but the light activation increases the amount of free radicals available to initiate the polymerization. Thus, the energy density provided by light-curing unit may have significant effect on polymerization kinetics and final DC (21). To simulate a clinical condition of ceramic cementation, light activation was performed through a 1.5-mm-thick ceramic disc. The interposition of a ceramic can lead to some attenuation of light depending on ceramic crystalline structure, light refractive index, shade and thickness $(5,9)$. The ceramics used during 
the light activation of cements resulted in an energy loss from light-curing unit varying from 11 to $22 \%$. However, this loss of energy did not result in reduction of DC irrespective the evaluated dual-cured cement (Table 2). The increased time of light-curing (120 s) may help to compensate the reduction of energy density, explaining the outcomes. Therefore, when dual-cured cement is lightcured through a ceramic system, extending light-curing time accordingly may still be necessary to achieve optimal polymerization (22). Furthermore, the $5 \mathrm{~min}$ of delay before the light-activation allows effective chemically activated polymerization (13).

Among the dual-cured cements, Allcem showed the highest values and Variolink II the lowest one, irrespective the conditions of light activation. Differences in composition, including amount of chemicals and photo-initiators, monomeric composition, ratio of diluent monomers and filler content can explain the results. However, considering that the exact concentration of each cement component is not provided by manufacturer, explanations of $\mathrm{DC}$ results based on composition are speculative. It is important to emphasize that differences of DC between resin cements do not necessarily indicate similar behavior when mechanical properties are evaluated (23). Interestingly, the behavior of hardness between the cements was similar to those observed for DC. In fact, beyond the compositional factors and the developed polymer structure, DC has important effect on hardness. However, despite the absence of differences between the ceramics for DC, the type of ceramic used during light activation significantly affected the hardness values for all cements.

Increased elastic modulus of resin cements reduces the stress over the restorative materials under occlusal loads and can improve the restoration longevity (24). In this study, all dual-cured resin cements behaved in the same way and better than the chemically cured cement, which may be explained by the lower filler volume, resulting in a flexible material with low $E$. Therefore, the null hypothesis was rejected since both the ceramic type and resin cement type affected the assessed properties.

Thus, according to the data obtained in this study, it may be concluded that the type of ceramic and resin cement affected the mechanical properties of the resin cements. The dual-cured resin cement showed better performance compared to chemically cured resin cement. Strong correlation between the mechanical properties (HV and $\mathrm{E}$ ) was shown; however, weaker correlations were found between both mechanical properties and DC.

Evaluation of the mechanical properties is important to predict the materials' behavior in clinical situations. The influence of the factors related to bonding strength with tooth and indirect restoration, handling properties, wear resistance, and color stability should be taken into account because they will also determine the clinical performance of the material (25). Future research should consider the polymerization of resin cements as function of time and ceramic thickness.

\section{Resumo}

0 objetivo deste estudo foi mensurar grau de conversão (GC), microdureza Vickers (VH) e módulo de elasticidade (E) de cimentos resinosos polimerizados através de diferentes sistemas cerâmicos. Um disco de 1,5 mm de espessura de cada sistema cerâmico (cerâmica feldspática, dissilicato de lítio e zircônia coberto por cerâmica feldspática) foi utilizado. Três cimentos resinosos duais (Allcem, Variolink II e RelyX U200) e um cimento resinoso quimicamente ativado (Multilink) foram ativados através dos discos de cerâmica. Para os cimentos resinosos duais foi utilizado um aparelho de lâmpada halógena (Optilux 501 a $650 \mathrm{~mW} / \mathrm{cm} 2$ por $120 \mathrm{~s}$ ). Amostras polimerizadas sem a interposição do disco de cerâmica foram utilizadas como controle. As amostras foram armazenadas a $37^{\circ} \mathrm{C}$ durante 24 h. ATR/FTIR foi utilizado para avaliar a extensão da polimerização nas amostras $(n=5)$. Propriedades micromecânicas - VH e E - dos cimentos resinosos $(n=5)$ foram medidas com um teste dinâmico de indentação. Os dados foram analisados através de análise de variância a dois fatores, teste de Tukey e correlação de Pearson $(\alpha=0,05)$. 0 GC foi afetado somente pelo tipo de cimento resinoso $(p=0,001)$. Para $\mathrm{VH}$, houve interação entre o tipo de cimento resinoso e o tipo de cerâmica $(p=0,045)$. Os cimentos resinosos duais não apresentaram diferenças significativas nos valores médios de E e valores significativamente maiores que o cimento resinoso quimicamente ativado. 0 grau de conversão e as propriedades mecânicas dos cimentos resinosos avaliados dependem do seu modo de ativação e do tipo de cerâmica usada na espessura de $1,5 \mathrm{~mm}$. 0 s cimentos resinosos duais desempenharam melhor que o cimento resinoso quimicamente ativado em todas as propriedades estudadas.

\section{References}

1. Cardash HS, Baharav H, Pilo R, Ben-Amar A. The effect of porcelain color on the hardness of luting composite resin cement. J Prosthet Dent 1993;69:620-623.

2. Pisani-Proenca J, Erhardt MC, Valandro LF, Gutierrez-Aceves G, Bolanos-Carmona MV, Del Castillo-Salmeron $\mathrm{R}$, et al.. Influence of ceramic surface conditioning and resin cements on microtensile bond strength to a glass ceramic. J Prosthet Dent 2006;96:412-417.

3. Rosenstiel SF, Land MF, Crispin BJ. Dental luting agents: A review of the current literature. J Prosthet Dent 1998;80:280-301.

4. Hackman ST, Pohjola RM, Rueggeberg FA. Depths of cure and effect of shade using pulse-delay and continuous exposure photo-curing techniques. Oper Dent 2002;27:593-599.

5. Tanoue N, Koishi Y, Atsuta M, Matsumura H. Properties of dual-curable luting composites polymerized with single and dual curing modes. J Oral Rehabil 2003;30:1015-1021.

6. Jung $H$, Friedl KH, Hiller KA, Haller A, Schmalz G. Curing efficiency of different polymerization methods through ceramic restorations. Clin Oral Investig 2001;5:156-161.

7. Bagis YH, Rueggeberg FA. The effect of post-cure heating on residual, unreacted monomer in a commercial resin composite. Dent Mater 2000;16:244-247.

8. Janda R, Roulet JF, Latta M, Kaminsky M, Ruttermann S. Effect of exponential polymerization on color stability of resin-based filling materials. Dent Mater 2007;23:696-704.

9. Heffernan MJ, Aquilino SA, Diaz-Arnold AM, Haselton DR, Stanford $\mathrm{CM}$, Vargas MA. Relative translucency of six all-ceramic systems. Part II: Core and veneer materials. J Prosthet Dent 2002;88:10-15.

10. O'Keefe $\mathrm{KL}$, Pease $\mathrm{PL}$, Herrin HK. Variables affecting the spectral transmittance of light through porcelain veneer samples. J Prosthet Dent 1991;66:434-438.

11. Kelly JR, Benetti P. Ceramic materials in dentistry: historical evolution 
and current practice. Aust Dent J 2011:56:84-96.

12. Bueno $A L$, Arrais $C A$, Jorge $A C$, Reis $A F, A$ maral $C M$. Light-activation through indirect ceramic restorations: does the overexposure compensate for the attenuation in light intensity during resin cement polymerization? J Appl Oral Sci 2011;19:22-27.

13. Faria-e-Silva AL, Moraes RR, Ogliari FA, Piva E, Martins LR. Panavia F: the role of the primer. J Oral Sci 2009;51:255-259.

14. Rueggeberg FA, Craig RG. Correlation of parameters used to estimate monomer conversion in a light-cured composite. J Dent Res 1988;67:932-937.

15. Rueggeberg FA, Hashinger DT, Fairhurst CW. Calibration of FTIR conversion analysis of contemporary dental resin composites. Dent Mater 1990;6:241-249.

16. Bicalho AA, Pereira RD, Zanatta RF, Franco SD, Tantbirojn D, Versluis $A$, et al.. Incremental filling technique and composite material--Part I: Cuspal deformation, bond strength, and physical properties. Oper Dent 2014;39:E71-E82.

17. Flury $S$, Lussi $A$, Hickel $R$, Ilie N. Light curing through glass ceramics: effect of curing mode on micromechanical properties of dual-curing resin cements. Clin Oral Investig 2014;18:809-818.

18. Wang L, D'Alpino PH, Lopes LG, Pereira JC. Mechanical properties of dental restorative materials: relative contribution of laboratory tests. J Appl Oral Sci 2003;11:162-167.

19. Oliver WC, Pharr GM. Measurement of hardness and elastic modulus by instrumental indentation: Advances in understanding and refinements to methodology. J Mater Res 2004;19:3-20.

20. Urabe H, Nomura $Y$, Shirai $K$, Yoshioka M, Shintani H. Influence of polymerization initiator for base monomer on microwave curing of composite resin inlays. J Oral Rehabil 1999;26:442-446.

21. Chen YC, Ferracane JL, Prahl SA. Quantum yield of conversion of the photoinitiator camphorquinone. Dent Mater 2007;23:655-664.

22. Zhang $X$, Wang F. Hardness of resin cement cured under different thickness of lithium disilicate-based ceramic. Chin Med J 2011;124:3762-3767.

23. Wydra JW, Cramer NB, Stansbury JW, Bowman CN. The reciprocity law concerning light dose relationships applied to BisGMA/TEGDMA photopolymers: theoretical analysis and experimental characterization. Dent Mater 2014;30:605-612.

24. Yokoyama D, Shinya A, Gomi H, Vallittu PK, Shinya A. Effects of mechanical properties of adhesive resin cements on stress distribution in fiber-reinforced composite adhesive fixed partial dentures. Dent Mater J 2012;31:189-196.

25. Lu H, Mehmood A, Chow A, Powers JM. Influence of polymerization mode on flexural properties of esthetic resin luting agents. J Prosthet Dent 2005;94:549-554. 